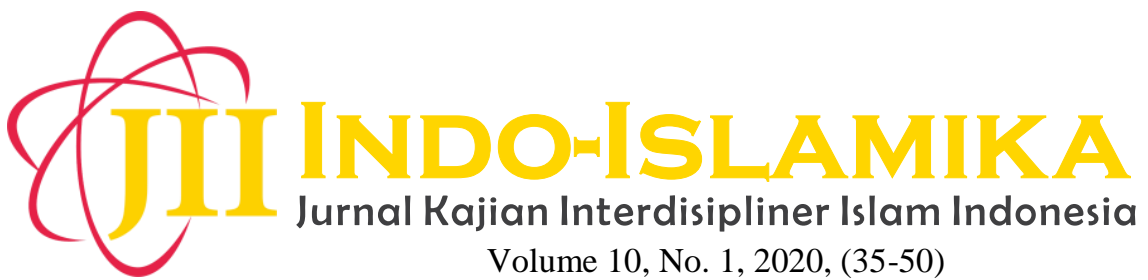

Sekretariat : Graduate School Syarif Hidayatullah State Islamic University (UIN) Jakarta

Website OJS : http://journal.uinjkt.ac.id/index.php/indo-islamika/index

E-mail : indoislamika@uinjkt.ac.id

\title{
Pengaruh KH. Hasyim Asy'ari dalam Membangun Serta Menjaga Nusantara dan Kemaslahatan Islam Dunia
}

\author{
Fakturmen, Muhammad Zaenul Arif \\ UIN Sunan Kalijaga Yogyakarta, Indonesia \\ Corresponding E-mail: fakturmen@gmail.com
}

\begin{abstract}
This article discusses about the influence of KH. Hasyim Asy'ari regarding his efforts in building and maintaining the integrity of the nation, both in the Islamic and national fields and his role in resolving the Islamic context at the International level (Hijaz). The research method used is literature study by means of descriptive content analysis. The results of this study indicate that KH. Hasyim Asy'ari is a figure who has a great influence in regulating national and Islamic stability both in thought (aqliyah) and movement (amaliyah) so that it stands the Unitary State of the Republic of Indonesia. Besides that, the important role of KH. Hasyim Asy'ari is both as an advisor and a legitimator in an effort to preserve the purity of Islam at the international level, namely the polemic of the sovereigns in the Hijaz land. The influence in the archipelago includes: the da'wah ukhuwah Islamiyah as a form of tolerance, the value of leadership towards the people and nation, intellectual contributions as Muslim scholars, influence and commitment against the invaders while his influence at the international level is to maintain the purity and benefit of the world Islam (Hijaz).
\end{abstract}

Keywords: KH. Hasyim Asy'ari, Nationalism, Islam, Hijaz Committee.

\begin{abstract}
Abstrak
Artikel ini membahas tentang pengaruh KH. Hasyim Asy'ari mengenai upayanya dalam membangun dan memelihara keutuhan bangsa, baik dalam bidang Islam maupun nasional serta perannya dalam menyelesaikan konteks Islam di tingkat Internasional (Hijaz). Metode penelitian yang digunakan adalah studi pustaka dengan cara analisis isi deskriptif. Hasil penelitian ini menunjukkan bahwa KH. Hasyim Asy'ari merupakan sosok yang memiliki pengaruh besar dalam mengatur stabilitas kebangsaan dan Islam baik dalam pemikiran (aqliyah) maupun pergerakan (amaliyah) sehingga berdiri sebagai Negara Kesatuan Republik Indonesia. Selain itu, peran penting KH. Hasyim Asy'ari sekaligus sebagai penasehat sekaligus legitimator dalam upaya menjaga kesucian Islam di tingkat internasional, yakni polemik para penguasa di tanah Hijaz. Pengaruh di nusantara meliputi: dakwah ukhuwah Islamiyah sebagai bentuk toleransi, nilai kepemimpinan terhadap umat dan bangsa, kontribusi intelektual sebagai cendekiawan muslim, pengaruh dan komitmen terhadap penjajah sedangkan pengaruhnya di tingkat internasional adalah untuk menjaga kemurnian dan kemaslahatan dunia Islam (Hijaz).
\end{abstract}

Kata Kunci: KH. Hasyim Asy'ari, Nasionalisme, Islam, Komite Hijaz. 



\section{PENDAHULUAN}

KH. Hasyim Asy'ari ${ }^{1}$ atau biasa dikenal dengan sebutan Hadratussyeikh Hasyim Asy'ari merupakan tokoh pembesar Islam yang banyak diperbincangkan dalam dua abad terakhir. Ia merupakan sosok ulama yang khas Indonesia. Sosok yang tidak hanya memiliki kecerdasan intelektual yang tinggi, tapi juga jiwa berorganisasi, pendidik, semangat bekerja, dan juga asketisisme yang tinggi ${ }^{2}$. Hal ini bisa dilihat dari jasa besarnya dalam membangun dan menjaga stabilitas kebangsaan dan keislaman yang ia terapkan dalam mewujudkan berdirinya NKRI.

Jasa-jasanya dalam membangun Nusantara sangat luar biasa, bahkan ia dikatakan sebagai peletak batu pertama kemerdekaan Indonesia ${ }^{3}$. Amiq menambahkan dalam artikelnya yang berjudul "Two Fatwas on Jihad Against the Dutch Colonization in Indonesia A Prosopographical Approach to the Study of Fatwa", kolonial Belanda dan Jepang sempat berusaha keras melakukan diplomasi dengan KH. Hasyim Asy'ari untuk diajak kerjasama, tapi hal itu gagal. Meski bantuan terus digelontorkan kepada pondok pesantren milik KH. Hasyim, ia tetap menolaknya dengan tegas ${ }^{4}$. Tidak hanya itu saja, bahkan demi mendapat simpati dan dukungan KH. Hasyim, Belanda sampai memberi gelar besar beliau sebagai sebuah "Bintang Emas", akan tetapi beliau menolaknya 5 .

Dalam bidang keislaman, KH. Hasyim juga memiliki andil besar dalam menjaga stabilitas persatuan antar umat muslim di Nusantara. Hal ini terlihat dari usahanya dalam menahan dan meluruskan semua hal yang bisa memecah belah antar umat muslim, seperti membentuk organisasi MIAI ${ }^{6}$. Selain itu pengaruh beliau dalam berdirinya organisasi NU (Nahdhlatul Ulama) dan pemimpin Masyumi ${ }^{7}$. Bahkan beliau merupakan satu-satunya pemimpin Nahdhlatul Ulama yang bergelar Rais Akbar.

Selain memiliki peran besar di tingkat Nasional, beliau juga memiliki pengaruh besar di kanca Internasional. Hal ini bisa tercermin dari pembentukan Komite Hijaz oleh kaum tradisional dan sekaligus melahirkan organisasi besar bernama Nahdhlatul Ulama dengan tujuan utama menyampaikan aspirasi penting kepada raja Ibnu Sa'ud yang mana sudah menguasai singgasana Hijaz ${ }^{8}$.

1 Tokoh Indinesia yang memiliki nama lengkap KH. Muhammad Hasyim bin Asy'ari itu merupakan pendiri sekaligus pemimpin organisasi besar di indonesia yang resmi lahir pada tahun 1926 M, yakni Nahdlatul Ulama (NU). Lahirnya organisasi ini merupakan berkat usaha dan ijtihad para Ulama Nusantara dalam menyatukan masyarakat (Islam) dalam bingkai Aswaja dan sebagai wadah atau lembaga yang berusaha selalu menjunjung tinggi harkat dan martabat bangsa dan negara Indonesia. Selain itu dalam perjalannya organisasi ini ini selalu mensuport dan membantu pemerintahan Indonesia. Lihat: Ali Rahim, "Nahdlatul Ulama (Peranan dan Sistem Pendidikannya)," Jurnal al-Hikmah 14, 2 (2013): 176.

2 Zuhairi Misrawi, Hadratussyaukh Hasyim Asy'ari: Moderasi, Keumatan, dan Kebangsaan (Jakarta: PT Kompas Media Nusantara, 2010), 27.

${ }^{3}$ Syahab Muhammad Asad, Al-'Allāmah Muhammad Hāsyim Asy'ari Wādhih Libnati Istiqlāli Indonesi (Beirut: Dār as-Shodiq, 1971), 11.

4 Amiq Amiq, "Two Fatwas on Jihad Against the Dutch Colonization in Indonesia A Prosopographical Approach to the Study of Fatwa," Studia Islamika 5, 3 (1998): 85.

${ }^{5}$ Syafi'in, "Kepemimpinan Profetik (Telaah kepemimpinan Pendidikan KH. Ahmad dahlan dan KH. Hasyim Asy’ari)” (Universitas Islam Negeri Maulana Malik Ibrahim Malang, 2020), 106.

${ }^{6}$ Syahab Muhammad Asad, Al-'Allāmah Muhammad Hāsyim Asy'ari Wādhih Libnati Istiqlāli Indonesia, 47.

${ }^{7}$ Abdul Hadi, K.H. Hasyim Asy'ari: Sehimpun Cerita, Cinta, Dan Karya Maha Guru Ulama Nusantara, Cetakan I (Yogyakarta: Diva Press, 2018), 35.

${ }^{8}$ Pembesar aliran Wahabi, yakni Ibn Sa'ud raja Najed pada tahun 1924 dan-1945 telah berhasil mengalahkan pemmimpin daerah Hijaz (Mekkah dan Madinah). Salah satu bentuk ketegangan yang terjadi pasca runtuhnya hijaz ketangan Ibn Sa'ud adalah dimana awalnya umat muslim yang selalu hidup 
Berdasarkan latar belakang di atas, masalah inti yang hendak digali oleh peneliti dalam artikel ini adalah menelusuri dan membedah kembali seputar pengaruh $\mathrm{KH}$. Hasyim Asy'ari di Nusantara baik dalam masalah keislaman maupun kebangsaan, serta pengaruhnya di tataran internasioanl. Sisi menarik dari topik yang di angkat ini adalah pengaruh KH. Hasyim Asy'ari di taraf internasional, dimana pembahasan ini jarang dibahas oleh para peneliti sebelumnya. Manfaat dari penelitian ini adalah untuk memberi khazanah dan refleksi baik para pembaca dan bagi peneliti pribadi melalui pemikiran KH. Hasyim Asy'ari. Dimana sampai sekarang masih saja ada gerakangerakan kelompok yang mengatasnamakan Islam, tapi ajarannya melenceng dari syari'at Islam, terutama Islam radikal. Menurut Tim Pusat Kajian Pemikiran KH. Hasyim Asy'ri Tebu Ireng, pemikiran maupun pergerakan mereka itu di dasari oleh anggapan bahwa agama tidak bisa disandingkan dengan ihwal kebangsaan, seperti Indonesia yang mayoritas islam tapi berideologi Pancasila ${ }^{9}$. Maka dari itu, penting sekali kita untuk menangkal paham-paham tersebut. Artikel ini diharapkan mampu menambah wawasan dan teladan terhadap sosok KH. Hasyim Asy’ari.

\section{METODE}

Metode yang digunakan dalam penelitian ini adalah studi pustaka (Library Research). Metode ini merupakan metode peneitian yang menggunakan cara memahami dan mendalami teori-teori yang diambil dari sumber literatur yang berhubungan dengan penelitian untuk dijadikan sebagai kumpulan data. Menurut Mestika Zed, metode penelitian ini memiliki empat tahapan, meliputi: siapkan alat yang diperlukan, siapkan bibliografi kerja, mengatur waktu dan membaca (pemahaman), serta mencatat materi (data) penelitian ${ }^{10}$.

Pengumpulan data diperoleh dari berbagai sumber seperti buku, artikel, majalah, arsip, dan dokumen-dokumen lain yang berkaitan dengan KH. Hasyim Asy'ari ${ }^{11}$. Adapun metode analisis menggunakan cara analisis konten dan analisis deskriptif. Datadata yang di dapat melalui literatur kemudian dipelajari secara kritis dan mendalam. Dalam penelitian ini, peneliti menggunakan cara yang disesuaikan dengan prinsip penelitian pustaka, agar memudahkan dalam proses analisis penelitian ${ }^{12}$.

\section{HASIL DAN PEMBAHASAN}

\section{Biografi Singkat KH. Hasyim Asy'ari}

Kyai yang akrab di panggil Mbah Hasyim ini memiliki nama lengkap Muhammad Hasyim Asy'ari. Ia dilahirkan dari keluarga keturunan kyai besar (keluarga

rukun meski berbeda-beda madzhab, kemudian dipaksa dan ditindas untuk mengikuti sistem wahabisme. Kemudian NU sebagai gerakan kaum tradisional mengirimkan delegasi ke Hijaz untuk menyampaikan surat mengai beberapa hal yang diminta oleh NU kepada pemimpin Hijaz (7 mei 1928). Dimana delegasi ini adalah kesempatan pas terkait diadakannya konggres di ijaz dengan mengundang seluruh kelompok muslim di dunia. Hal ini dimanfaatkan NU untuk menyampaikan aspirasinya. Lihat: A. Khoirul Anam, A. Zuhdi Muhdlor, dkk, Ensiklopedia Nahdlatul Ulama (Jilid 1) (Jakarta Pusat: Mata Bangsa dan PBNU, 2014), 233.

9 Tim Pusat Kajian Pemikiran KH. Hasyim As'ari, Sikap Keislaman dan Kebangsaan Hadratussyaikh KH. M. Hasyim Asy'ari, Cetakan 1 (Jombang, Indonesia: Pustaka Tebu Ireng, 2018), 9. 2004), 14

10 Mustika Zed, Metode Penelitian Kepustakaan (Jakarta: Yayasan Pustaka Obor Indonesia,

11 Bungaran Anthonius Simandjuntak dan Soedjito Sosrodihardjo, Metode Analisis Sosial (Jakarta: Yayasan Pustaka Obor Indonesia, 2014).

12 Klaus Krippendorff, Content Analysis an Introduction to Its Methodology (London: International Education and Profwssional Publisher, 2004), 18. 
pesantren $)^{13}$ di Jawa pada tanggal 14 Februari 1871 (24 Dzulqa'dah 1287) dikota Jombang Jawa Timur, tepatnya di desa Gedang ${ }^{14}$. KH. Hasyim merupakan anak ketiga dari pasangan Kyai Asy'ari dan Ibu Halimah dan memiliki 10 saudara kandung ${ }^{15}$. Kesepuluh saudaranya adalah Nafiah, Ahmad Shaleh, Radjah, Hasan, Anis, Fathanah, maimunah, Ma'sum, Nahrawi, dan Adnan. Adapun jalur keturunan ia dari jalur bapak adalah M. Hasyim Asy'ari bin Asy'ari bin Abdul Wakhid bin Abdul Halim (Pangeran Benawa) bin Abdurrahman (Jaka Tingkir) bin Abdullah bin Abdul Aziz bin Abdul Fattah bin Maulana Ishaq bin Ainul Yaqin (Sunan Giri). Sedangkan dari jalur Ibu adalah M. Hasyim Asy'ari binti Halimah binti Layyinah bin Sihah bin Abdul Jabbar bin Ahmad bin Pangeran Sambo bin Pangeran Benawa bin Jaka Tingkir bin Lembu Peteng (Prabu Brawijaya VI) ${ }^{16}$.

Melihat jalur silsilah di atas, KH. Hasyim Asy'ari memiliki dua trah sekaligus, yaitu: trah bangsawan (aristokrat) Jawa dan pembesar agama (elit agama), dalam hal ini Islam. Dari jalur bapak, ia nyambung sampai bangsawan muslim Jawa, yakni Jaka Tingkir atau Sultan Hadiwijaya (Abdurrahman) dan juga Sunan Giri (Ainul Yaqin) sebagai seorang elit agama. Sedangkan dari jalur Ibu, ia nyambung sampai ke trah Bangsawan Hindhu Jawa, yakni Lembu Peteng (Raja Brawijaya IV) ${ }^{17}$. Alwi Shihab menambahkan, bahwa KH. Hasyim juga memiliki trah Basyaiban yaitu darah keturunan para Da'i Timur Tengah (Arab) dari Ahl al-Bait yang melakukan penyebaran Islam di Asia Tenggara, termasuk Indonesia pada abad ke-14 ${ }^{18}$.

KH. Hasyim Asy'ari merupakan Kyai yang memiliki kecerdasan yang sangat luar biasa. Sejak masih dikandungan ibunya sudah merasakan keanehan terhadap bayi kandungannya tersebut. Hal ini setelah ia bermimpi melihat bulan yang ada dilangit itu jatuh dan tepat jatuh ke dalam kandungan bu Halimah. Tentu mimpi ini bukan suatu hal yang biasa saja, melainkan tanda-tanda keajaiban kehebatan mbah Hasyim ketika lahir nanti. Makanya tidak heran jika ketika mbah Hasyim umur 13 tahun sudah berhasil menguasai berbagai ilmu, termasuk ilmu bahasa Arab. Bahkan ia sudah diberi izin untuk mengajar di pondok ayahnya tersebut ${ }^{19}$.

Menginjak usia 15 tahun Kyai Hasyim Asy'ari memutuskan belajar ke pondokpondok di pulau Jawa Madura, seperti: pesantren Wonocolo Jombang, Pesantren Purbalingga, pesantren Langitan, pesantren Trangilis (Semarang), termasuk belajar di

${ }^{13}$ Bukti keturunan bahwa beliau dilarihkan dari golongan pesantren dapat dilihat dari silsilah beliau. Kakek buyut beliau adalah pendiri pondok pesantren Tambak Beras, yakni KH. Sihah. Kemudian Kakek beliau merupakan pendiri pondok besar di gedang, yakni Kyai Ustman. Kemudian bapak beliau Kyai Asy'ari juga pengasuh pondok pesantren Karas Jombang. Lihat: Hartono Margono, “KH. Hasyim Asy'ari dan Nahdlatul Ulama: Perkembangan Awal dan Kontemporer," Media Akademika 26, 3 (2011): 336-337.

${ }^{14}$ Lathiful Khuluq, “K.H. Hasyim Asy’ari’s Contribution to Indonesian Independence," Studia Islamika 5, 1 (1998), 46.

${ }^{15}$ Muhammad Zaim, "Kompetensi Kepribadian Guru menurut KH. hasyim Asy’ari dalam Kitab Adab Al-'Alim wa Al'Muta'aalim,” Murobbi: Jurnal Ilmu Pendidikan 4, 2 (2020): 91.

${ }^{16}$ Achmad Muhibbin Zuhri, Pemikiran KH. M. Hasyim Asy'ari tentang Ahl al-Sunnah wa alJama'ah (Surabaya: Khalista, 2010), 67.

${ }^{17}$ Achmad Muhibbin Zuhri, Pemikiran KH. M. Hasyim Asy'ari tentang Ahl al-Sunnah wa alJama'ah (Surabaya: Khalista, 2010), 68.

18 Alwi Shihab, Islam Sufistik: "Islam Pertama” dan Pengaruhnya hingga Kini di Indonesia (Bandung: Mizan, 2001), 117. 2011), 89 .

${ }^{19}$ Ni'am Syamsun, Wasiat Tarekat Hadratus Syaikh hasyim Asy'ari (Jogjakarta: Ar-Ruzz Media, 
Pondok Pesantren Kyai Kholil Bangkalan Madura ${ }^{20}$. Tidak lama dari pondok KH Kholil, ia memutuskan pindah pondok di Siwalan Sidoarjo (1891) yang terkenal dengan pengasuhnya yang alim dan berpandangan luas yaitu KH. Ya'qub. Mbah Hasyim mondok di Siwalan cukup lama yakni sekitar lima tahunan ${ }^{21}$.

Pada tahun 1893, ia dianjurkan oleh KH. Ya'qub untuk berangkat ke Mekkah untuk menuntut ilmu ${ }^{22}$. Selama 7 tahun belajar disana, kemudian ia pulang ke tanah air dan meneruskan pondok kakeknya Kyai Utsman di Jombang.

Tepat pada tanggal 2 juli 1947, KH. Hasyim Asy'ari dikabarkan meninggal dunia akibat penyakit darah tinggi atau strok. Ia meninggal pasca di sowani (menerima tamu) oleh utusan Bung Tomo dan Jendral Sudirman untuk menyampaikan kabar mengenai agresi militer Belanda I. Kabar tersebut berisi tentang pasukan Belanda sudah berhasil mengalahkan tentara Indonesia dan menguasai wilayah Singosari (Malang) dengan cara memboncengi sekutu yang dipimpin Jendral SH. Poor. Tidak hanya itu saja, korban yang jatuh juga banyak yang dari golongan masyarakat sipil, sehingga korban jiwa yang meninggal sangatlah banyak. Hal ini berdasarkan situs resmi milik Pesantren Tebuireng setelah menjelaskan secara detai peristiwa tersebut ${ }^{23}$.

\section{Pengaruh KH. Hasyim Asy'ari}

Secara garis besar peran dan pengaruh KH. Hasyim Asy'ari di Indonesia meliputi dua aspek, meliputi: aspek keislaman dan aspek kebangsaan ${ }^{24}$. Pada aspek keislaman yang di maksud disini adalah aktivitas dan pemikiran KH. Hasyim dalam menjaga kemurnian agama Islam. Sedangkan aspek kebangsaan adalah berupa aktivitas dan pemikirannya terhadap Bangsa Indonesia.

Adapun pengaruh KH. Hasyim Asy'ari dalam tingkat Internasional adalah pengaruhnya dalam menjaga kemaslahatan Islam dunia dengan melegitimasti pembentukan panitia Hijaz.

\section{Dakwah Ukhuwah Islamiyah sebagai bentuk Toleransi}

KH. Hasyim Asy'ari merupakan ulama besar yang sangat mencintai kerukunan sesama umat muslim. Meski memiliki pandangan yang berbeda, ia selalu memposisikan dirinya di tengah-tengah, sehingga konflik apapun yang terjadi, ia berusaha menahan dan menyelesaikan kedalam jalan perdamaian. Tidak itu saja, bahkan ia sangat tidak suka dengan adanya kelompok atau aliran yang suka menyalahkan kelompok lain. Maka

${ }^{20}$ Mukhlis Lbs, “Konsep Pendidikan menurut Pemikiran KH. Hasyim Asy’ari,” As-Salam 4, no. 1 (2020): 83 .

${ }^{21}$ Mukhlis Lbs, “Konsep Pendidikan menurut Pemikiran KH. Hasyim Asy’ari,” 90-91.

${ }^{22}$ Setelah mendapat himbauan dari KH. Ya’qub, KH. Hasyim Asy’ari langsung berangkat ke Mekkah. Disana ia berguru kepada ulama-ulama besar, meliputi: Syech Ahmad Amin al-Attar, Sayyid Sultan bi Hasyim, Sayyid Ahmad bin Hassan al-Attas, Syeich Said al-yamani, Sayyid 'Alawwi bin Ahmad al-Saqqaf, Sayyid Abbas al-Maliki, dan masih banyak ulama-ulama Mekkah lainnya. Selain itu ia juga belajar kepada Ulama Indonesia yang mengajar di mekkah, seperti: Syaikh Ahmad Khatib Minangkabawi, Syaikh Nawawi al-Bantani, dan Syaikh Mahfudz al-Timrisi. Ketiga ulama tersebut merupakan guru besar diu Mekkah yang juga memberikan keilmuan dana pengaruh besar terhadap KH. Hasyim Asy'ari. Lihat: Matsuki HS dan M. Ishom edt El-Saha, Intelektualisme Pesantren, Potret Tokoh dan Cakrawala Pemikiran di Era Perkembangan Pesantren (Jakarta: Diva Pustaka, 2003), 75-76.

${ }^{23}$ Zuhri, Pemikiran KH. M. Hasyim Asy'ari tentang Ahl al-Sunnah wa al-Jama'ah,71.

${ }^{24}$ Muhammad Rijal Fadli dan Ajat Sudrajat, "Keislaman Dan Kebangsaan: Telaah Pemikiran KH. Hasyim Asy’ari,” Khazanah: Jurnal Studi Islam dan Humaniora 18, 1 (2020). 
dari itu, KH. Hasyim tidak henti-hentinya mengajak kepada seluruh kaum muslim untuk bersatu dan menjaga ukhuwah islamiyah ${ }^{25}$.

Meski hal ini dirasa KH. Hasyim sangat berat untuk diaplikasikan, tapi bukan tidak mungkin untuk tetap dilakukan. Berdasarkan sejarah memang perpecahan sudah terjadi dari masa setelah meninggal Nabi Muhammad dengan perebutan kekuasan oleh sekte Anshār dan sekte Muhäjirin. Akan tetapi hal ini dapat diselesaikan. Fakta lain yang menunjukkan gambaran perpecahan umat Islam adalah dilihat dari hadits Nabi Muhammad saw, bahwa Islam akan pecah menjadi 73 aliran, dimana ke semua aliran tersebut akan masuk neraka, kecuali satu aliran, yakni ajaran Ahli as-Sunnah wa al$J_{a m \bar{a}}{ }^{\prime} a h^{26}$.

Akan tetapi KH. Hasyim tidak pesimistis terhadap hal ini, karena bagi beliau menjaga ukhuwah islāmiyah merupakan bagian dari ajaran agama ${ }^{27}$. Hal ini juga tertuang dalam Mukaddimah Qonun Asasi bahwa pentingnya sebuah organisasi, bermasyarakat, untuk mencapai suatu tujuan tertentu. Selain itu dikatakan bahwa persatuan, ikatan batin seseorang dengan yang lainnya, saling menghormati, saling membantu merupakan faktor terkuat terciptanya kebagiaan dalam menciptakan persaudaraan dan kasih sayang ${ }^{28}$.

Sikap kooperatif KH. Hasyim dalam menjaga persatuan umat Islam menunjukkan sikap toleransi dan moderat. Salah satu sikap yang dikemukakan adalah ketika menghadiri Muktamar NU ke-11 di Banjarmasin ${ }^{29}$. Sikap ini sebenarnya merupakan respon KH. Hasyim terhadap munculnya paham-paham atau aliran Islam baru, sekitar tahun $1330 \mathrm{H}(1908 \mathrm{M})$ di Indonesia ${ }^{30}$. Menurut KH. Ali Ma'shum, kefanatikan kelompok yang lahir dari suatu kesalah pemahaman akan berakibat memecah belah antar umat muslim ${ }^{31}$.

Sebagai bentuk keresahan KH. Hasyim Asy'ari terhadap konflik ini, ia berusaha berfikir keras mencari solusi bagaimana cara menyatukan semua golongan muslim. Ia berpandangan bagaimana bisa sesama umat muslim yang Tuhan-nya satu, Kitab-nya satu Al-Qur'an, Nabi-nya satu Nabi Muhammad. Atas dasar itulah pada tanggal 21 September 1937, ia mendirikan organisasi yang mampu menghimpun seluruh aliran umat muslim dengan membentuk MIAI (Majlis Islam A'la Indonesia), dimana ini adalah organisasi Islam pertama yang mengumpulkan kaum muslim antar aliran dalam satu organisasi ${ }^{32}$. Dikatakan juga bahwa ajakan ukhuwah islāmiyah ini juga merupakan

Indonesi, 47

${ }^{25}$ Syahab Muhammad Asad, Al-'Allāmah Muhammad Hāsyim Asy'ari Wādhih Libnati Istiqlāli

${ }^{26}$ Hadits di atas merupakan hadits Nabi riwayat Imam Abu dawud dan Imam at-Tirmidzi dan Ibnu Majah dari Imam Abu Huraitah ra. Lihat: Muhammad Hasyim Asy’ari, Risalah Ahlu as-Sunnah wa Al-Jama'ah (Jombang: Maktabah At-Thuros Al-Islami, t.t), 23.

${ }^{27}$ Ahmad Khoirul Fata dan M Ainun Najib, “Kontekstualisasi Pemikiran Kh. Hasyim Asy'Ari Tentang Persatuan Umat Islam,” MIQOT: Jurnal Ilmu-ilmu Keislaman 38, 2 (2014): 329.

28 A. Khoirul Anam, A. Zuhdi Muhdlor, dan Dkk, Ensiklopedia Nahdlatul Ulama (Jilid 4) (Jakarta Pusat: Mata Bangsa dan PBNU, 2014), 18.

${ }^{29}$ Rifai Muhammad, K.H. Hasyim Asy'ari Biografi Singkat 1871-1947 (Yogyakarta: Ar-Ruzz Media, 2010), 111-112.

${ }^{30}$ Asy'ari, Risalah Ahlu as-Sunnah wa Al-Jama'ah, 9.

${ }^{31}$ A Zuhdi Mukhdlor, K.H. Ali MA'SHUM Perjuangan dan Pemikiran-pemikirnanya, ed. Ahmad Wakhid Mubarok (Yogyakarta: Multi Karya Grafika Yogyakarta, 1989), 64. Indonesi, 47.

32 Syahab Muhammad Asad, Al-'Allāmah Muhammad Hāsyim Asy'ari Wāahih Libnati Istiqlāli 
kesepakatan KH. Hasyim dengan salah satu ulama besar Timur Tengah yakni al'Allämah Syeikh Muhammad Husein Abi Kasyif as-Shata'33.

Ajakan KH. Hasyim Asy'ari untuk selalu menjaga kerukunan antar pemeluk seagama (Islam) ini sebenarnya juga sesuai dengan ajaran Al-Qur'ān dan Hadits. Maka dari itu, ia berusaha untuk memberikan pandangan dan penjelasan yang luas mengenai hal ini. Seperti halnya dalam al-Qur'an surat al-Hujarat ayat 9-10, yang menjelaskan bahwa begitu fundamentalnya menjaga keharmonisan suatu umat beragama (Islam). Jika terjadi konflik antara dua kubu yang sama-sama muslim maka harus di leraikan dan di satukan kembali. Dengan jalan penyelesaian yang tidak merugikan kedua belah pihak melalui pengadilan yang adil ${ }^{34}$.

KH. Hasyim menegaskan bahwa "jika memang dia itu Islam, ya tetap Islam (tidak kafir). Maka sesungguhnya perkara-perkara tersebut merupakan perbedaan pendapat dan perkara yang bersifat furu'iyah ${ }^{35}$, tidak mungkin untuk memecah belah terhadap kalimatnya umat Islam dalam keadaan apapun. Maka sesungguhnya perkaraperkara ini yakni yang memiliki perbedaan itu merupakan perkara yang bersifat sepele" 36 .

Dari penjelasan di atas dapat dipahami bahwa nilai Ukhuwah Islämiyah itu berada di atas segala kepentingan aliran apapun. Bercermin dari KH. Hasyim bahwa tingkat keimanan seorang muslim merupakan cerminan dari perilakunya. Seorang muslim yang sejati tidak mungkin melakukan hal-hal yang mampu memecah belah antar sesama saudaranya (muslim). Hal ini tentu sebagai pelajaran yang berharga khususnya bagi umat muslim dimana banyak yang mementingkan kebenaran kelompoknya dari pada menjaga perasaan orang lain. Maka dari itu untuk mencapai keridhoan Ilāhiyah, kita sering lupa dengan hubungan kita dengan sesama manusia, tidak mampu merealisasikan tuntunan hidup yang sebenarnya dan tidak mengetahui tujuan hidup yang sesungguhnya. Maka dari itu, hal ini perlu kita ketahui secara komprehensif.

\section{Kontribusi Intelektual sebagai Cendekiawan Muslim}

KH. Hasyim merupakan tokoh Islam/ ulama nusantara yang memiliki keunikan dibanding ulama yang lain, yaitu kecerdasannya dalam mengarang kitab. Dibanding kyai-kyai yang lain, KH. Hasyim jauh memiliki tulisan (kitab) yang banyak dengan berbagai fan keilmuan. Tidak hanya kecerdasan dalam menulis atau mengarang kitab, ia juga memiliki jiwa sosial (amal) yang sangat kuat, yakni berupa pengabdiannya terhadap umat. Maka dari itu, keteladanan yang dapat kita warisi adalah pemikiranpemikirannya yang direalisasikan dalam bentuk amaliyah-amaliyah terhadap umat dan juga keilmuan beliau yang dituangkan dalam kitab-kitab pesantren (Kutub al-Turāts) ${ }^{37}$.

\footnotetext{
${ }^{33}$ Rifai Muhammad, K.H. Hasyim Asy'ari Biografi Singkat 1871-1947, 67.

${ }^{34}$ M Quraish Shihab, Al-lubab "Makna, Tujuan, dan Pelajaran dari Surah-Surah al-Qur'an" (Tangerang: Lentera Hati, 2012), 9-10.

${ }^{35}$ Menurut KH. Ali M'shoem: kepada seluruh umat muslim jika ada perbedaan terutama masalah furu'iyyah (bukan syar'i) di antara kalian, jangan suka menyebarkan fitnah, perdebatan yang niatnya untuk menjatuhkan, dan membenci baik terhadap orang yang bertanya, pelaku, maupun orang atau kelompok yang memang berbeda dengan kalian. Semua ini adalah hal yang tidak perlu untuk kalian permasalahkan d antara sesama muslim. Lihat: Ma'shum Ali, Hujjah Ahl As-Sunnah wa Al-Jamā'ah (Jogjakarta: Putera Menara Jogjakarta, 1983), 7.

36 Syahab Muhammad Asad, Al-'Allāmah Muhammad Hāsyim Asy'ari Wāahih Libnati Istiqlāli Indonesi.

${ }^{37}$ Misrawi, Hadratussyaukh Hasyim Asy'ari: Moderasi, Keumatan, dan Kebangsaan, 94.
} 
Beberapa bidang keilmuan yang di keluarkan KH. Hasyim Asy'ari adalah meliputi bidang pendidikan, akidah (teologi), tasawuf (sufisme), fikih dan hadis. Dalam buku Rifa'i mengatakan bahwa KH. Kholil Bangkalan yang merupakan salah satu guru KH. Hasyim Asy'ari mengakui bila muridnya itu merupakan seorang ahli hadis ${ }^{38}$.

Selain itu, karya KH. Hasyim Asy'ari juga dijadikan sebagai sumber keilmuan atau khazanah ilmu yang diajarkan oleh pondok pesantren. Pesantren cenderung di tujukan untuk mencetak SDM yang berintelektual dalam bidang agama dan bisa menyesuaikan situasi yang ada dimasyarakat nantinya. Dalam mewujudkan cita-cita ini, posisi seorang ulama/tokoh yang alim sangat dibutuhkan, yang nantinya akan memimpin dan menstransfer ilmunya kepada santrinya ${ }^{39}$.

Puncak dari pemikiran KH. Hasyim adalah ketika pandangan, keilmuan, dan pengaruhnya dijadikan sebagai nilai dan ruh dari umat kalangan ahli sunnah wa aljamā'ah dan bagaimana nilai tersebut di internalisasikan dan diinstitusionalkan menjadi sebuah organisasi terbesar di dunia, yakni Nahdlatul Ulama (NU) ${ }^{40}$.

Maka dari itu, karya-karya KH. Hasyim dapat dikatakan sebagai harta/karya yang bersifat transformatif. Karena melalui pemikiran KH. Hasyim yang dinamis dan toleran, serta inspiratif ini mampu menjadikan perbedaan sebagai suatu bagian yang harus dijaga. Bahkan mampu menjadi pelindung umat muslim secara universal tanpa memandang etnis atau kelompok tertentu.

Adapun karya-karya intelektual KH. Hasyim Asy'ari yang berhasil di abadikan adalah sebagaimana yang telah diabadikan oleh cucunya, yakni KH. Isham Handziq. Semua tulisan karya KH. Hasyim Asy'ari kebanyakan ditulis menggunakan kalimat bahasa Arab, dan beberapa dengan bahasa Jawa. Berikut adalah karya-karya tersebut: al-Tibyān fi al-Nahy 'an Muqātha'at al-Arhām wa al-'Aqārib wa al-Ikhwān, Muqaddimah al-Qānūn al-Asāsī li Jam'iyyat Nahdlatul Ulamā, Risālah fi Ta'kīd al Akhdzi bi Madzhab al-A'immah al-Arba'ah, Muwā'idz, Arba'īna Hadìtsan Tata'allaq bi Mabādi Jam'iyyat Nahdlatul Ulama, Al-Nūr al-Mubìn fi Mahabbati Sayyid alMursalīn, Al-Tambihāt al-Wajibāt li Man Yashna' al-Maulid bi al-Munkarāt, Risālah Ahl al-Sunnah wa al-Jamā'ah fi Hadits al-Mautā wa Syurūth al-Sā'ah wa Bayāni Mafhūm al-Sunnah wa al-Bid'ah, Ziyādat Ta'līqāt 'alā Mandzūmah Syaikh 'Abdullāh bin Yāsīn al-Fāsuruan̄̄, Dhaw'il Misbāh fi Bayān Ahkām al-Nikāh, Al-Dzurrah alMuntasyirah fi Masāil Tis'asyarah, Al-Risālah fi al-'Aqāid, Al-Risālah al-Tasawwuf, dan Adab al-'Alim wa al-Muta'allim fi Ahwal Ta'limihi wa Yatawaqqafu 'Alaihi alMuta'allim fi Maqamāti Ta'līmihi'.

Selain itu, dikatakan bahwa masih ada beberapa karya KH. Hasyim Asy'ari yang belum dicetak, dan masih dalam bentuk manuskrip.

Dengan demikian, KH. Hasyim Asy'ari adalah Kyai yang memiliki kecerdasan intelektual yang tinggi. Tidak hanya memiliki semangat cinta tanah air, tapi juga memiliki kecerdasan keilmuannya yang tidak hanya untuk dirinya sendiri tapi juga ia ajarkan ke orang lain (masyarakat luas), khususnya kaum tradisionalis. Selain itu, ajaran-ajarannya mampu memberikan suntikan rasa semangat menjunjung rasa cinta terhadap tanah air ini. Sehingga dapat dikatakan sosok KH. Hasyim Asy'ari adalah

${ }^{38}$ Rifai Muhammad, K.H. Hasyim Asy'ari Biografi Singkat 1871-1947, 13.

${ }^{39}$ Syahab Muhammad Asad, Al-'Allāmah Muhammad Hāsyim Asy'ari Wādhih Libnati Istiqlāli Indonesi, 21-22.

${ }^{40}$ Zuhri, Pemikiran KH. M. Hasyim Asy'ari tentang Ahl al-Sunnah wa al-Jama'ah, 44.

${ }^{41}$ Misrawi, Hadratussyaukh Hasyim Asy'ari: Moderasi, Keumatan, dan Kebangsaan, 96-99. 
sosok Kyai yang peduli dengan umat dang bangsa, dimana pengaruhnya sangat diperhatikan oleh para pengikutnya, bahkan aliran yang lain.

\section{Nilai Kepemimpinan terhadap Umat dan Bangsa}

Sejak kanak-kanak jiwa-jiwa kepemimpinan KH. Hayim Asy'ari sudah mulai terlihat. Ketika bermain dengan teman-temannya, ia sering menjadi sosok penengah, dan murah mengalah. Ketika temannya-temannya berantem, ia selalu melerai dan menenagkan keduanya. Jika temannya ada salah ia selalu memaafkannya. Ia selalu membuat temnnya ceria dan nyaman bermain dengannya. Sehingga ia cenderung disukai teman-temannya ${ }^{42}$.

Selain memiliki intelektual yang tinggi, KH. Hasyim Asy'ari juga memiliki rasa kepedulian yang tinggi tehadap umat dan bangsa ini yang kategorinya majemuk. Sifat rendah hati, pelindung dan penyayang sangat melekat pada diri KH. Hasyim Asy'ari. ${ }^{43}$ Pola sikap seperti ini yang menjadikan ia selalu disegani dan dihormati oleh umat muslim yang lain. Sehingga tidak heran jika ia mampu meredam ketegangan yang sering terjadi antara kaum tradisionalis dengan kaum pembaharu (modrnis).

Sikap kepemimpinan memang selalu dipegang oleh KH. Hasyim Asy'ari dalam memberi keputusan. Hal ini terlihat pada tahun 1926, disaat Hijaz jatuh ke tangan Wahabi (Ibn Saud), KH. Hasyim melegitimasi dibentuknya panitia Hijaz sebgai penyampai aspirasi kaum tradisional ke penguasa $\mathrm{Hijaz}^{44}$. Selain itu dalam rapat tersebut melahirkan organisasi baru, yakni Nahdlatul Ulama (NU) dan KH. Hasyim Asy'ari ditunjuk sebagai Rais Akbar ${ }^{45}$. Hal ini menunjukkan pengaruh KH. Hasyim Asy'ari atau dalam hal ini nilai kepemimpinan dan pemikiran ia sangat di hormati dalam kalangan ulama tradisional. ${ }^{46}$

Rasa cinta yang kuat juga ditunjukkan KH. Hasyim Asy’ari kepada umat Islam dengan membentuk organisasi keislaman, yaitu MIAI (Majlis Islam A'la Indonesia) pada tanggal 21 September 1937. Latar belakang lahirnya organisasi ini adalah dimana saat itu banyak aliran islam yang masuk di Indonesia, sehingga umat muslim banyak yang berdeda pendapat dan menimbulkan perpecahan. Hal ini sangat diresahkan oleh KH. Hasyim. Ia berfikir bagaimana menyatukan semua aliran tersebut, hingga akhirnya ia berinisiatif mencover dengan membentuk MIAI tersebut ${ }^{47}$.

Akan tetapi akhirnya pada tanggal 24 Oktober 1943 Jepang membubarkan MIAI dan menggantinya dengan partai baru, yaitu: MASYUMI (Majlis Syuro Muslimin Indonesia). Hal ini karena ada kepentingan penjajajah Jepang, mereka merasa bahwa organisasi ini tidak sesuai dengan kebijakan pemerintah (Jepang) ${ }^{48}$. Adapun peran KH. Hasyim dalam organisasi ini adalah sebagai ketua kehormatan, dan sekaligus ditunjuk sebagai dewan penasehat. Meski semenjak meninggalnya KH. Hasyim, organisasi NU

${ }^{42}$ Ni'am Syamsun, Wasiat Tarekat Hadratus Syaikh hasyim Asy'ari, 89.

${ }^{43}$ Misrawi, Hadratussyaukh Hasyim Asy'ari: Moderasi, Keumatan, dan Kebangsaan, 28.

44 A. Khoirul Anam, A. Zuhdi Muhdlor, dan Dkk, Ensiklopedi Nahdlatul Ulama (Jilid 2) (Jakarta Pusat: Mata Bangsa dan PBNU, 2014), 192.

${ }^{45}$ Zuhri, Pemikiran KH. M. Hasyim Asy'ari tentang Ahl al-Sunnah wa al-Jama'ah, 138.

${ }^{46}$ Muhibbin Zuhri menambahkan, bahwa KH. Hasyim Asy'ari merupakan representasi yang tepat dari ideologi Sunni (ahl al-Sunnah wa al-Jama'ah). Maka dari itu, selain ditunjuk sebagai Rais Akbar NU, ia juga dijadikan sebagai ideolog NU mengenai ahl al-Sunnah wa al-Jama'ah. Lihat: Zuhri, Pemikiran KH. M. Hasyim Asy'ari tentang Ahl al-Sunnah wa al-Jama'ah, 44.

47 Syahab Muhammad Asad, Al-'Allāmah Muhammad Hāsyim Asy'ari Wādhih Libnati Istiqlāli Indonesi, 47-48.

${ }^{48}$ Rifai Muhammad, K.H. Hasyim Asy'ari Biografi Singkat 1871-1947, 67. 
memilih keluar dari organisasi MASYUMI dengan alasan tidak ada tokoh yang berpengaruh seperti KH. Hasyim Asy'ari.

Selain itu, pada 13 maret 1944 ia juga ditunjuk sebagai Kepala Kementrian Urusan Agama menggantikan Husen Djadjadiningrat yang di anggap gagal oleh Jepang. Akan tetapi pengangkatan ini hanya bersifat simbolik, sedangkan untuk tugasnya diserahkan kepada putranya KH. Wahid Hasyim ${ }^{49}$. Dikatakan juga bahwa ia ditunjuk sebagai penasehat PETA (Pembela Tanah Air) yang merupakan prajurit sukarela buatan Jepang ${ }^{50}$. Hal yang menarik dari ini adalah bahwa KH. Hasyim tidak pernah mau melakukan kerja sama dengan penjajah. Namun hal ini berbeda dengan posisi penjajah Jepang. Dimana Jepang dirasa mampu menjadi bahan sandungan menuju Indonesia merdeka.

Dari berbagai kemampuan dan keberhasilan KH. Hasyim Asy'ari dalam memimpin suatu organisasi kebangsaan, semakin meningkatkan karismanya. Sehingga tidak dipungkiri jika ia mampu menjadi pemimpin banyak organisasi-organisasi Islam, seperti MIAI, Masyumi, dan NU. Posisi yang ia jabat ini tidak hanya sebagai sosok pemimpin saja, melainkan juga menjadi sosok yang paling disegani diantara muslim yang lain, sehingga $u k h u w a h$ atau rasa persatuan antar sesama anggota organisasi tetap berjalan dengan baik ${ }^{51}$. Meski sebenarnya amanah kepemimpinan itu sering ditolak oleh KH. Hasyim Asy'ari sendiri, karena bentuk amaliyah beliau bukan karena untuk mendapatkan jabatan, melainkan karena cinta terhadap agama, bangsa dan negara karena Allah Ta'āla ${ }^{52}$.

Dari penjelasan di atas, nilai kepemimpinan yang ditunjukkan KH. Hasyim Asy'ari merupakan nilai kepemimpinan yang lahir dari kemurnian jiwa KH. Hasyim yang didasari oleh rasa cinta terhadap bangsa dan umat. Tingkat kecerdasan dan pengalamannya yang tinggi juga menjadikannya kuat dalam berbagai situasi yang dihadapinya. Hal penting juga yang perlu diteladani dari sosoknya adalah melihat semua kepada sisi maslahah /kebaikan semua golongan. Sehingga keputusan-keputusan yang di ambil beliau selalu menghasilkan hasil yang maslahah pula.

\section{Pengaruh dan Komitmen dalam Melawan Penjajah}

Rasa nasionalisme sebenarnya sudah ditunjukkan KH. Hasyim Asy'ari terhadap keputusannya dalam memilih lokasi pondok pesantren di Tebuireng. Pasalnya lokasinya relatif terpencil, jauh dari pusat pemerintahan kolonial Belanda. Kemudian juga terlihat dari sikap ia yang melarang umatnya dalam mengikuti kebiasaan-kebiasaan Belanda ${ }^{53}$. Hal ini menunjukkan sikapnya kalau menolak terhadap segala apa yang dilakukan oleh Belanda bahkan keberadaanya cenderung menjauhi. Akan tetapi, belanda merasa bahwa eksistensi KH. Hasyim Asy'ari semakin membahayakan penjajah Belanda. maka dari itu, pada tahun 1913 pondok KH. Hasyim dibakar Belanda ${ }^{54}$. Meski begitu, KH. Hasyim tidak jera dibuatnya, ia tetap saja bersikukuh untuk melawan Belanda.

Tahun 1942, merupakan jatuhnya pemerintahan Belanda oleh Jepang di Kalijati. Akan tetapi hal ini tidak menjadikan rakyat Indonesia terutama kaum muslim lega.

\footnotetext{
${ }^{49}$ Rifai Muhammad, K.H. Hasyim Asy'ari Biografi Singkat 1871-1947, 122.

${ }^{50}$ Gugun El-Guyanie, Resolusi Jihad Paling Syar'i (Yogyakarta: PT LKiS Perinting Cemerlang, 2010), 43.

${ }^{51}$ Rifai Muhammad, K.H. Hasyim Asy'ari Biografi Singkat 1871-1947, 20.

52 Syahab Muhammad Asad, Al-'Allāmah Muhammad Hāsyim Asy'ari Wādhih Libnati Istiqlāli Indonesi, 22.

${ }^{53}$ Rifai Muhammad, K.H. Hasyim Asy'ari Biografi Singkat 1871-1947, 113.

${ }^{54}$ Rifai Muhammad, K.H. Hasyim Asy'ari Biografi Singkat 1871-1947, 113-114.
} 
Pasalnya dengan hadirnya Jepang justru malah menindas rakyat dengan perlakuanperlakuan yang biadab terutama kepada kaum muslim ${ }^{55}$.

Akan tetapi hal ini tidak menyurutkan nasionalisme KH. Hasyim dan santrinya dalam melawan penjajah. Hal ini diperlihatkan KH. Hasyim dengan tidak mau dan mengharamkan hormat terhadap jepang atau diistilahkan "Seikeirei". Ia juga berfatwa kalau hormat kepada Jepang itu tidak boleh, hanya kepada Allah lah kita menyembah ${ }^{56}$. Dalam misinya Jepang selalu menindas rakyat dan membunuh para santri yang melawan. Bahkan karena begitu kawatirnya Jepang terhadap kaum santri yang dipimpin KH. Hasyim Asy'ari, Jepang sempat menangkat KH. Hasyim dan mengrungnya dengan sekenario yang sudah dibuat oleh Jepang. Akan tetapi setelah 6 bulan, ia dibebaskan oleh Jepang (18-8-1942) ${ }^{57}$.

Pada masa mendaratnya sekutu yang di susupi juga oleh Belanda di Indoinesia pada 21-22 Oktober 1945, KH. Hasyim mengajak ulama-ulama NU untuk melakukan musyawarah sebagai respon ia terhadap munculnya sekutu di Indonesia. Masalah utama yang akan dibahas adalah mengenai status hukum NKRI yang telah diproklamasikan Ir. Soekarno dan Moh. Hatta pada 17 Agustus 1945 itu $^{58}$. Rapat ini memakan waktu hingga dua hari. Hasil yang sepakati dalam musyawarah ini adalah bahwa NKRI berdasarkan Pancasila itu sah secara fikih. Maka dari itu, mempertahankan negara dan melawan penjajah hukumnya wajib (fadlu 'ain) bagi warga dengan radius 94 KM dari kota Surabaya.

Maklumat ini sering disebut sebagai "Resolusi Jihad" "59. Dimana mengakibatkan peperangan yang amat besar dan banyak korban berjatuhan termasuk kaum muslim (santri). Peperangan ${ }^{60}$ ini terjadi pada 10 November 1945 di kota Surabaya. Kebanyakan korban yang gugur adalah para santri KH. Hasyim Asy'ari dan juga warga Surabaya. Hal ini menjadi tragedi yang sangat pilu dalam sejarah penjajahan Indonesia ${ }^{61}$.

Meskipun gagasan Resolusi Jihad KH. Hasyim Asy'ari tidak dicantumkan dalam buku sejarah nasional sebagai bagian sejarah kuat melawan penjajah, akan tetapi secara nasional hari peperangan 10 November menjadi hari Pahlawan Nasional Indoinesia. Dimana peristiwa ini merupakan peristiwa besar atas gagasan yang dikeluarkan oleh KH. Hasyim Asy'ari62. Selain itu, pada 17 November 1964, KH. Hasyim ditetapkan sebagai Pahlawan Nasional.

Dikabarkan bahwa detik ahir hayat KH. Hasyim Asy'ari adalah dalam kondisi mengawal Kemerdekaan, tepatnya pada bulan Ramadhan bakda salat tarawih. Ia merasa kurang sehat dan pingsan pasca disowani oleh Bung Tomo dan Jendral Sudirman ${ }^{63}$.

${ }^{55}$ Misrawi, Hadratussyaukh Hasyim Asy'ari: Moderasi, Keumatan, dan Kebangsaan, 87.

${ }^{56}$ Rifai Muhammad, K.H. Hasyim Asy'ari Biografi Singkat 1871-1947, 122.

57 Syahab Muhammad Asad, Al-'Allāmah Muhammad Hāsyim Asy'ari Wādhih Libnati Istiqlāli Indonesi, 33-34.

58 Alamul Huda, "Epistemologi Gerakan Liberalis, Fundamentalis, Dan Moderat Islam Di Era Modern," Journal de Jure 2, 2 (2010), 191.

59 Bobi Fadli, M. Rijal dan Hidayat, "KH. Hasyim Asy’ari dan Resolusi Jihad dalam Usaha Mempertahankan Kemerdekaan Indonesia," Jurnal Swarnadwipa 2, 1 (2018): 62

60 KH. Hasyim Asy'ari sebagai Rais Akbar NU mendeklarasikan sebuah seruan Jihad fi sabilillah (Resolusi Jihad) untuk melawan tentara sekutu dan belanda dimana rapat koordinasinya dipimpin oleh KH. Wachab Hasbullah. Lihat: El-Guyanie, Resolusi Jihad Paling Syar'i, 74.

${ }^{61}$ A. Khoirul Anam, A. Zuhdi Muhdlor, dkk, Ensiklopedia Nahdlatul Ulama (Jilid 3) (Jakarta Pusat: Mata Bangsa dan PBNU, 2014), 171.

62 Masgono, Resolusi Jihad KH. Hasyim Asy'ari (Jakarta, 2012).

${ }^{63}$ Zuhri, Pemikiran KH. M. Hasyim Asy'ari tentang Ahl al-Sunnah wa al-Jama'ah, 71. 
Kemudian pada waktu sahur tepatnya jam 03.00 WIB 7 ramadhan atau tanggal 25 Juli 1947 beliau dikabarkan wafat ${ }^{64}$.

Dengan penjelasan di atas, peran pemikiran KH. Hasyim Asy'ari dalam menegakkan semangat nasionalisme di tanah air sangat tinggi. Selain itu, rasa kecintaan terhadap umat dan bangsa juga ia perlihatkan kepada seluruh umat. Sehingga tidak heran jika setiap gagasan yang ia keluarkan selalu diikuti oleh umat ataupun santrinya. Bahkan karena begitu berpengaruhnya KH. Hasyim Asy'ari dikalangan muslim, hal ini membuat kolonial Belanda maupun Jepang sampai ketakutan sehingga usaha menjatuhkan beliau terus dilakukan. Tragedi puncak yang didasari oleh legitimasi melawan penjajah adalah ketika KH. Hasyim mengeluarkan maklumat Resolusi Jihad pada 22 Oktober 1945, sehingga mengakibatkan peperangan yang sangat dahsyat pada 10 November 1945.

\section{Menjaga Kemurnian dan Kemaslahatan Islam Dunia (Komite Hijaz)}

Panitia Hijaz atau lebih dikenal dengan komite Hijaz merupakan panitia yang berisi ulama tradisional yang dibuat atas dasar menyelamatkan kemaslahatan dan kemurnian Islam dunia dari tangan Wahabi ${ }^{65}$. Latar belakang lahirnya panitia ini ada dua alasan penting. Pertama, dikuasainya daerah Hijaz yang meliputi Mekkah dan Madinah oleh Ibn Saud yang beraliran Wahabi, sehingga menimbulkan kecemasan diantara ulama-ulama tanah air, terutama kaum tradisional. Hal ini juga diperkuat setelah mendengar kabar bahwa kegiatan ziarah makam Nabi dan sahabat, bahkan makam Nabi akan di bongkar, serta larangan kebebasan bermadzhab ${ }^{66}$. Kedua, pada tahun 1926 terjadi pengambilan keputusan sepihak oleh kaum modernis perihal delegasi ulama yang akan dikirimkan ke Hijaz dengan tidak melibatkan kaum tradisionalis, sehingga kaum tradisonalis berinisiatif membuat panitia baru ${ }^{67}$.

Peran penting yang dilakukan KH. Hasyim Asy'ari ${ }^{68}$ dalam misi ini adalah merestui (legitimasi) gagasan yang diajukan oleh KH. Wachab Hasbullah untuk membuat panitia Hijaz dalam rangka mempertahankan kebebasan kaum muslim dalam bermadzhab di Hijaz (Mekkah dan Madinah) ${ }^{69}$.

${ }^{64}$ Misrawi, Hadratussyaukh Hasyim Asy'ari: Moderasi, Keumatan, dan Kebangsaan, 92.

${ }^{65}$ Menurut Noorhaidi : kelompok salafi kontemporer (wahabi kontemporer) merupakan inovasi dari bentuk wahabi yang lama dengan berusaha menyusun ideologi secara sistematis yang tidak meninggalkan ajaran-ajaran wahabi klasik, yaitu: Ibn Taimiyah, Ibn al-Qoyyim al-jauziyyah, dan Muhammad Abdul Wahhab. Serta ulama-ulama wahabi lainnya. Lihat: Noorhaidi Hasan, Laskar Jihad: Islam, Militansi, dan Pencarian Identitas di Indonesia Pasca Orde Baru (Jakarta: LP3ES, 2008), 34.

${ }^{66}$ Anam, Muhdlor, dan Dkk, Ensiklopedi Nahdlatul Ulama (Jilid 2), 191.

${ }^{67}$ M. Ali Haidar, Nahdlatul Ulama dan Islam di Indonesia: pendekatan Fikih dalam Politik (Jakarta: Gramedia Pustaka Utama, 1994), 58.

${ }^{68}$ Legitimasi yang diberikan oleh KH. Hasyim ini sebenarnya tidak langsung diterima oleh KH. Wachab. Pasalnya KH. Hasyim sejak awal sudah khawatir dan mencegah perpecahan diantara umat muslim nusantara, yakni kaum tradisionalis dan kaum modernis yang berisi Muhammadiyah dan SI. Maka dari itu, awalnya beliau tidak merestui ide tersebut. Akan tetapi akhirnya KH. Hasyim memberikan legitimasi untuk membentuk panitia terkait delegasi Hijaz dan juga menjadi pelopor lahirnya organisasi Nahdlatu Ulama (NU). Hal ini sebagaimana ditegaskan Fearly, bahwa "perubahan keputusan KH Hasyim Asy'ari mengenai pembentukan panitia Hijaz yang awalnya tidak disetujui olehnya menjadi sah direstui olehnya. Hal ini pasca tidankan sepihak oleh kaum moderns yang dimulai sejak 1925 yang disangka membuat KH. Hasyim kecewa”. Lihat: Greg Fealy dan Barton Barton, Tradisionalisme Radikal, Persinggungan Nahdlatul Ulama Negara (Yogyakarta: LKiS, 1997).

69 Margono, “KH. Hasyim Asy’ari dan Nahdlatul Ulama: Perkembangan Awal dan Kontemporer," 341. 
Tepatnya pada 31 Januari 1926 ulama-ulama tradisional mengadakan rapat pembentukan Panitia Hijaz. Dalam rapat dipimpin KH. Wachab dengan mengundang tokoh-tokoh ulama tradisional senior, meliputi KH. Hasyim Asy'ari, KH. Asnawi Kudus, KH. Bisri Syamsuri, dan para ulama-ulama lainnya. Pembahasan utama yang di musyawarahkan dalam rapat ini adalah membahas isi surat yang akan dikirimkan Raja Saud yang berisi pemikiran-pemikiran ulama Tradisional dan juga memilih delegasi ulama yang akan menyampaikan surat tersebut. Karena dalam mendelegasikan perwakilan ulama harus disertai utusan lembaga formal, maka dibentuklah organisasi sebagai wadah ulama tradisional dengan nama Nahdlatul Ulama (NU). Nama ini digagas oleh KH. Mas Alwi ${ }^{70}$. Keputusan delegasi ulama yang akan mewakili adalah KH. Asnawi Kudus ${ }^{71}$.

Adapun hasil dari musyawarah tersebut menhasilkan beberapa aspirasi ulama tradisonal terkait kebijakan yang telah dikeluarkan Ibn Sa'ud. Adapun isi keputusan tersebut meliputi:

a. Pemberlakuan kemerdekaan bermadzhab di daerah Hijaz baik Mekkah dan Madinah kepada salah satu madzhab empat, yang terdiri dari: Imam Maliki, Imam Hambali, Imam Syafi'i. Dan Imam Hanafi.

b. Agar tempat-tempat bersejarah tetap diabadikan, karena tempat tersebut merupakan wakaf untuk masjid, seperti: tempat kelahiran Siti Fatimah dan tempat bersejarah lainnya.

c. Agar disebarluaskan ke seluruh dunia setiap tahun sebelum jatuhnya musim haji mengenai hal ikhwal, baik ongkos haji, perjalanan keliling mekkah kepada Syaikh maupun Muthowwif.

d. Semua hukum yang berlaku dinegri hijaz, hendaknya ditulis sebagai undang-undang supaya tidak terjadi pelanggaran yang hanya dilatarbelakangi belum adanya pembukuan undang-undang tersebut oleh pihak pemerintah.

e. Jam'iyyah NU memohon balasan surat secara tertulis yang menerangkan bahwa surat ini sudah sampai ke hadapan raja Ibn Sa'ud dan sudah pula di baca. ${ }^{72}$

Permintaan ulama NU yang disampaikan melalui surat tersebut ternyata sampai dan di dengar oleh Raja Ibn Saud, meski tidak semuanya diterima olehnya. Adapun permintaan yang dikabulkan oleh Ibn Saud adalah mengenai kebebasan bermadzhab oleh masyarakat muslim di daerah Hijaz. Kemudian juga komitmen yang diberikan untuk memberi layanan dan informasi mengenai Haji dan kebutuhannya. Serta hal yang paling penting dimana diperbolehkannya berziarah ke makam Rasulullah saw. ${ }^{73}$ Dengan ini artinya makam Rasulullah tetap diabadikan. Berita ini sangat memberi suasana gembira bagi kalangan muslim Indonesia terutama kaum tradisional (NU) dimana merekalah yang menggagas pemikiran ini.

Adapun peranan KH. Hasyim dalam kegiatan ini (Panitia Hijaz) adalah melegitimasi dan merestui pendirian organisasi Nahdlatul Ulama (NU). Sekaligus ia ditunjuk sebagai Rais Akbar (Ketua Pusat) organisasi NU. Hal yang sangat menunjukkan warna dan corak NU sangat dipengaruhi KH. Hasyim adalah ketika ia berpidato sebagai pembuka organisasi NU disampaikannya asas-asas NU yang menganut satu madzhab dari empat Imam madzhab, yakni Syafi'iyyah. Selain itu,

\footnotetext{
${ }^{70}$ Anam, Muhdlor, dan Dkk, Ensiklopedi Nahdlatul Ulama (Jilid 2), 192.

${ }^{71}$ Zuhri, Pemikiran KH. M. Hasyim Asy'ari tentang Ahl al-Sunnah wa al-Jama'ah, 137-138.

72 Anam, Muhdlor, dan Dkk, Ensiklopedi Nahdlatul Ulama (Jilid 2), 192.

${ }^{73}$ Misrawi, Hadratussyaukh Hasyim Asy'ari: Moderasi, Keumatan, dan Kebangsaan, 289.
} 
Muqaddimah kitab karangan KH. Hasyim mengenai NU Qonun Asasy dijadikan sebagai bagian utuh dari Anggaran Dasar $\mathrm{NU}^{74}$.

Selain kiprah dalam misi Hijaz, KH. Hasyim juga pernah mendapatkan mandat sebagai ketua kehormatan di salah satu organisasi di tingkat luar negri. Hal ini sesuai dengan catatan Asad Syihab, bahwa KH. Hasyim Asy'ari pernah mendapatkan penghargaan sebagai Ketua Kehormatan Organisasi Pemuda Muslim di Kairo, yakni: "Jam'iyyatu al-Syubbān al-Muslimīn". 75

Dua poin penting yang perlu digaris bawah dari misi ini adalah: pertama, selain pembentukan panitia ini sebagai bentuk aspirasi kaum tradisional atas nama ulama Indonesia kepada penguasa Hijaz. Juga didasari pada kemaslahatan Islam global, dimana Hijaz merupakan pusat keilmuan (studi Islam) dan disana banyak sekali ulamaulama dan pelajar, termasuk dari Indonesia. Maka posisi Hijaz sangat fundamental bagi kemaslahatan muslim di dunia. Kedua, KH. Hasyim sebagai pembesar (Rais Akbar NU) muslim tradisionalis memiliki andil besar dalam misi ini. Hal ini bisa dilihat bahwa legalnya surat dan delegasi untuk masuk di kerajaan Ibn Sa'ud harus melalui organisasi yang jelas. Dengan posisi KH. Hasyim dijadikan sebagai Rais Akbar dalam organisasi NU, maka surat itu bisa di terima bahkan dibalas dengan isi surat pengabulan beberapa permintaan ulama NU, salah satunya adalah pengabulan kebebasan dalam bermadzhab bagi muslim Hijaz. Selain itu juga yang membuat NU lega adalah dengan di cabutnya kegiatan penggusuran makamnya Nabi Muhammad.

\section{KESIMPULAN}

KH. Hasyim Asy'ari merupakan tokoh muslim yang memiliki pribadi yang besar. Ia memiliki jiwa pemimpin, pendidik, pejuang, dan kecerdasan intelektual yang sangat tinggi. Maka tidak heran pada 17 November 1964 beliau dijadikan sebagai Pahlawan Nasional. Pemikiran-pemikirannya tidak hanya di patuhi oleh kalangan muslim saja, tapi kalangan nasionalis juga meminta nasehat kepadanya. Bahkan, sampai musuhpun (penjajah) takut dan berusaha menjatuhkannya.

Pengaruh besar KH. Hasyim Asy'ari dalam membangun dan menjaga nusantara terdiri dari pemikiran keislaman dan pemikiran kebangsaan. Pemikiran keislaman meliputi: dakwah ukhuwah islamiyah sebagai bentuk toleransi dan kontribusi intelektual sebagai cendekiawan muslim. Kemudian pemikiran kebangsaan meliputi: nilai kepemimpinan, dan pengaruh dan komitmen dalam melawan penjajah. Adapun pengaruh di tingkat dunia adalah pengaruh KH. Hasyim Asy'ari dalam menjaga kemurnian dan kemaslahatan Islam dunia (Komite Hijaz). Inilah pengaruh besar KH. Hasyim Asy'ari, baik di Nusantara maupun di dunia. Maka dari itu, sebagai generasi penerus bangsa mari belajar dari pemikiran dan keteladanan KH. Hasyim Asy'ari untuk menjaga dan menegakkan keutuhan Negara Kesatuan Republik Indonesia (NKRI).

\section{DAFTAR PUSTAKA}

Amiq, Amiq. "Two Fatwas on Jihad Against the Dutch Colonization in Indonesia A Prosopographical Approach to the Study of Fatwa.” Studia Islamika 5, 3 (1998).

Anam, A. Khoirul, A. Zuhdi Muhdlor, dkk. Ensiklopedi Nahdlatul Ulama (Jilid 2). Jakarta Pusat: Mata Bangsa dan PBNU, 2014.

Anam, A. Khoirul, A. Zuhdi Muhdlor, dkk. Ensiklopedia Nahdlatul Ulama (Jilid 1).

74 Margono, "KH. Hasyim Asy'ari dan Nahdlatul Ulama: Perkembangan Awal dan Kontemporer," 340-341.

${ }^{75}$ Syahab Muhammad Asad, Al-'Allāmah Muhammad Hāsyim Asy'ari Wādhih Libnati Istiqlāli Indonesi, 22. 
Jakarta Pusat: Mata Bangsa dan PBNU, 2014.

Anam, A. Khoirul, A. Zuhdi Muhdlor, dkk. Ensiklopedia Nahdlatul Ulama (Jilid 3). Jakarta Pusat: Mata Bangsa dan PBNU, 2014.

Anam, A. Khoirul, A. Zuhdi Muhdlor, dkk. Ensiklopedia Nahdlatul Ulama (Jilid 4). Jakarta Pusat: Mata Bangsa dan PBNU, 2014.

Asy'ari, Syeh Muhammad Hasyim. Risalah Ahlu as-Sunnah wa Al-Jama'ah. Jombang: Maktabah At-Thuros Al-Islami, t.t.

El-Guyanie, Gugun. Resolusi Jihad Paling Syar'i. Yogyakarta: PT LKiS Perinting Cemerlang, 2010.

Fadli, M. Rijal dan Hidayat, Bobi. "KH. Hasyim Asy'ari dan Resolusi Jihad dalam Usaha Mempertahankan Kemerdekaan Indonesia." Jurnal Swarnadwipa 2, no. 1 (2018).

Fadli, Muhammad Rijal, dan Ajat Sudrajat. "Keislaman Dan Kebangsaan: Telaah Pemikiran KH. Hasyim Asy'ari." Khazanah: Jurnal Studi Islam dan Humaniora 18, 1 (2020).

Fata, Ahmad Khoirul, dan M Ainun Najib. "Kontekstualisasi Pemikiran Kh. Hasyim Asy’Ari Tentang Persatuan Umat Islam.” MIQOT: Jurnal Ilmu-ilmu Keislaman 38, 2 (2014).

Fealy, Greg, dan Barton Barton. Tradisionalisme Radikal, Persinggungan Nahdlatul Ulama Negara. Yogyakarta: LKiS, 1997.

Hadi, Abdul. K.H. Hasyim Asy'ari: Sehimpun Cerita, Cinta, Dan Karya Maha Guru Ulama Nusantara. Yogyakarta: Diva Press, 2018.

Haidar, M. Ali. Nahdlatul Ulama dan Islam di Indonesia: pendekatan Fikih dalam Politik. Jakarta: Gramedia Pustaka Utama, 1994.

Hasan, Noorhaidi. Laskar Jihad: Islam, Militansi, dan Pencarian Identitas di Indonesia Pasca Orde Baru. Jakarta: LP3ES, 2008.

HS, Matsuki, dan M. Ishom edt El-Saha. Intelektualisme Pesantren, Potret Tokoh dan Cakrawala Pemikiran di Era Perkembangan Pesantren. Jakarta: Diva Pustaka, 2003.

Huda, Alamul. "Epistemologi Gerakan Liberalis, Fundamentalis, Dan Moderat Islam Di Era Modern." Journal de Jure 2, 2 (2010).

Khuluq, Lathiful. "K.H. Hasyim Asy'ari's Contribution to Indonesian Independence." Studia Islamika 5, 1 (1998).

Krippendorff, Klaus. Content Analysis an Introduction to Its Methodology. London: International Education and Profwssional Publisher, 2004.

Lbs, Mukhlis. "Konsep Pendidikan menurut Pemikiran KH. Hasyim Asy'ari." As-Salam 4, 1 (2020).

Ma'shum Ali. Hujjah Ahl As-Sunnah wa Al-Jamā'ah. Jogjakarta: Putera Menara Jogjakarta, 1983.

Margono, Hartono. “KH. Hasyim Asy’ari dan Nahdlatul Ulama: Perkembangan Awal dan Kontemporer." Media Akademika 26, 3 (2011).

Masgono. Resolusi Jihad KH. Hasyim Asy'ari. Jakarta, 2012.

Misrawi, Zuhairi. Hadratussyaukh Hasyim Asy'ari: Moderasi, Keumatan, dan Kebangsaan. Jakarta: PT Kompas Media Nusantara, 2010.

Mukhdlor, A Zuhdi. K.H. Ali Ma'shum Perjuangan dan Pemikiran-pemikirnanya. Diedit oleh Ahmad Wakhid Mubarok. Yogyakarta: Multi Karya Grafika Yogyakarta, 1989.

Ni'am Syamsun. Wasiat Tarekat Hadratus Syaikh hasyim Asy'ari. Jogjakarta: Ar-Ruzz 
Media, 2011.

Rahim, Ali. "Nahdlatul Ulama (Peranan dan Sistem Pendidikannya)." Jurnal al-Hikmah 14, 2 (2013).

Rifai Muhammad. K.H. Hasyim Asy'ari Biografi Singkat 1871-1947. Yogyakarta: ArRuzz Media, 2010.

Shihab, Alwi. Islam Sufistik: "Islam Pertama" dan Pengaruhnya hingga Kini di Indonesia. Bandung: Mizan, 2001.

Shihab, M Quraish. Al-lubab "Makna, Tujuan, dan Pelajaran dari Surah-Surah alQur'an". Tangerang: Lentera Hati, 2012.

Simandjuntak, Bungaran Anthonius, dan Soedjito Sosrodihardjo. Metode Analisis Sosial. Jakarta: Yayasan Pustaka Obor Indonesia, 2014.

Syafi'in. "Kepemimpinan Profetik (Telaah kepemimpinan Pendidikan KH. Ahmad dahlan dan KH. Hasyim Asy'ari)." Universitas Islam Negeri Maulana Malik Ibrahim Malang, 2020.

Syahab Muhammad Asad. Al-'Allāmah Muhammad Hāsyim Asy'ari Wādhih Libnati Istiqlāli Indonesi. Beirut: Dār as-Shodiq, 1971.

Tim Pusat Kajian Pemikiran KH. Hasyim As'ari. Sikap Keislaman dan Kebangsaan Hadratussyaikh KH. M. Hasyim Asy'ari. Jombang, Indonesia: Pustaka Tebu Ireng, 2018.

Zaim, Muhammad. "Kompetensi Kepribadian Guru menurut KH. hasyim Asy'ari dalam Kitab Adab Al-'Alim wa Al'Muta'aalim." Murobbi: Jurnal Ilmu Pendidikan 4, 2 (2020).

Zed, Mustika. Metode Penelitian Kepustakaan. Jakarta: Yayasan Pustaka Obor Indonesia, 2004.

Zuhri, Achmad Muhibbin. Pemikiran KH. M. Hasyim Asy'ari tentang Ahl al-Sunnah wa al-Jama'ah. Surabaya: Khalista, 2010. 